\title{
Zinc Finger Homeobox Protein 3
}

National Cancer Institute

\section{Source}

National Cancer Institute. Zinc Finger Homeobox Protein 3. NCI Thesaurus. Code C115426.

Zinc finger homeobox protein 3 (3703 aa, 404 kDa) is encoded by the human ZFHX3 gene. This protein is involved in cellular differentiation and transcriptional repression. 